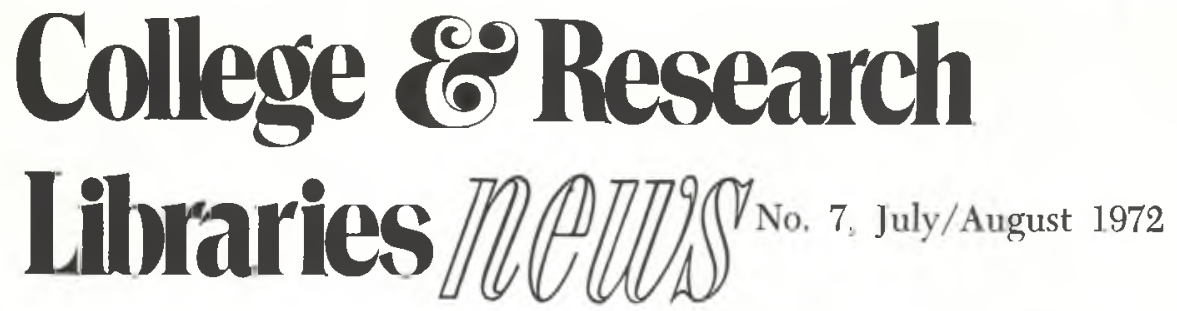

ACRL News Issue (A) and (B) of College \& Research Libraries, Vol. 33, No. 4

\title{
Annual Report of the President, 1971-72
}

Among the chief concerns of ACRL members during the past year were academic status, greater autonomy for divisions within the structure of ALA, and the editorship of CHOICE. For the past two or three years the ACRL Committee on Academic Status has been developing "Standards for Faculty Status for College and University Librarians"; membership adopted the statement last June at Dallas. The board of directors had previously approved the statement in principle and authorized the committee to use the document as a negotiating instrument with representatives of the Association of American Colleges and the American Association of University Professors. The three organizations (AAC, AAUP and ACRL) set up a joint committee on College Library Problems which has prepared a "Joint Statement on the Faculty Status of Librarians." The statement was reviewed during the Chicago Conference by our Committee on Academic Status which reported its recommendations to the board.

For the past several years ACRL members have been expressing concern about the limited clout the division carries within the ALA structure; some have suggested complete withdrawal from ALA and the setting up of an independent organization; others have opted for remaining but believe there should be more power and greater autonomy for the divisions. The officers of ACRL and of the American As- sociation of School Librarians met in Dallas and again during the Chicago Midwinter Meeting in January to talk about the problem and to "feel" each other out. The conversations have resulted in an interdivisional committee composed of representatives from AASL, ACRL and the American Library Trustee Association, under the chairmanship of Anne C. Edmonds, past president of ACRL. The committee met during the Chicago Conference to map strategy and develop a program which the divisions, hopefully, will be able to support when and if the reorganization of ALA structure is considered.

The dismissal of Peter Doiron, editor of CHOICE, last July 29 caused no small amount of uneasiness among ACRL members from that date until now. For several months, at least until Midwinter, officers and staff devoted most of their time to reading and replying to letters and other forms of communication related to this matter. On January 11, $1972 \mathrm{Mr}$. Doiron submitted a Request for Action to the ALA Staff Committee on Mediation, Arbitration and Inquiry (SCMAI). Since they were named as principals in Mr. Doiron's dismissal, the executive director of ALA and the executive secretary of ACRL removed themselves from SCMAI as this case was considered. With Mrs. Ruth Frame, executive secretary of the Library Administration Division, as chairman, SCMAI

\footnotetext{
College \& Research Libraries is published by the Association of College and Research Libraries, a division of the American Library Association, 17 times yearly-6 bimonthly journal issues and II monthly, combining July. August, News issues at 1201-05 Bluff St. Fulton, Ma. 65251. Subscription, $\$ 10.00$ a year or, to members of the division, $\$ 5.00$ included in dues. Circulation and advertising office: American Library Association, 50 E. Huron St. Chicago, III. 606ll. Second-class postage paid at Fulton, Missouri 65251.

News edifor: Michael Herbison, Library, University of Colorado, Colorado Springs Center, Colorado Springs, Colorado 80907. Editor: Richard M. Dougherty, School of Library Science, Syracuse University, Syracuse, N.Y.
} 13210. President, ACRL: Russell Shank. 
appointed a fact-finding subcommittee composed of Robert Donahugh, Gerald Shields and Myrl Ricking, chairman. The subcommittee has written its report and upon the recommendation of SCMAI it was published in the June 1972 issue of American Libraries. The factfinding subcommittee recommended among other things, that the ALA Executive Board grant a formal hearing to Mr. Doiron. Meanwhile, with Don Thomas doubling as executive secretary and editor, and with the very able and devoted cooperation of the four assistant editors, CHOICE has met its publication deadlines and seems not to have suffered in quality.

As a direct result of their frustrations over matters of money-the decision by COPES to use $\$ 50,000$ which CHOICE had earmarked for development of the journal, the refusal to finance an Office for Academic Status, the threat to treat money-making journals within ALA in the same manner as subsidized journals, the ACRL membership at the Dallas Conference overwhelmingly approved a resolution suggesting that personal members of ACRL be assessed $\$ 5.00$ and institutional members be assessed $\$ 10.00$ above their regular dues for the support of the proposed Office for Academic Status. A committee composed of the chairmenelect of the five ACRL sections was appointed to investigate the feasibility of levying additional fees on ACRL members; the committee reported at the Midwinter Meeting and it was decided that the total membership should be given an opportunity to express its reactions to a matter of this gravity. Consequently, a ballot was prepared for publication in the May issue of CRL News and a poll of membership was conducted.

ACRL approved the "Guidelines for Two Year College Library Learning Resource Centers" and made provision for them to be reviewed annually. Under this provision a revision of the guidelines worked out with representatives of the Association for Educational Communications and Technology was brought to the ACRL Board at the Chicago Meeting.

A subsection on Anthropology has been established in the Subject Specialists Section and an $\mathrm{Ad} \mathrm{Hoc} \mathrm{Committee} \mathrm{on} \mathrm{Bibliographic} \mathrm{In-}$ struction formed. The latter is planning to operate a clearinghouse on library instructional programs.

The Committee on Cooperation with Educational and Professional Organizations became

\footnotetext{
BUSINESS - COMMERCE - ECONOMICS Specialists in Out $\rightarrow$ f-Print Books in the Social Sciences Want Lists Searched

Collections Fulfilled-Catalogs Issued HIVE OF INDUSTRY, BOOKSELLERS Box 602
}

dissatisfied with their former practice of having lunch with a few representatives of other organizations and decided that they would like to become more greatly involved with social issues. Accordingly, the committee has rewritten its statement of purpose and has taken steps to assist the libraries of some of the predominately Negro colleges, a move similar to that of the ARL Committee which cooperates with the Negro Research Libraries Subcommittee of the COSATI Library Panel.

The 1972 Program Planning Committee with advice from the ACRL Audiovisual Committee arranged a program entitled "The Educational Dynamics of Media" as our contribution to the Chicago Conference. Two sections and six of the subsections of ACRL planned and made arrangements for program meetings at Chicago. The Junior College Libraries Section sponsored a preconference on "Developing Services for the Total Community" at the University of Illinois, Champaign, June 23 and June 24 and the Rare Books and Manuscripts Section (note the new name) held a preconference at the Drake Hotel, Chicago, June 22-24, entitled "MidWestern Scholarly Resources: the Outward Reach of the Midwest to the Scholarly World." With it all, we look forward to 1973 and Las Vegas. The ACRL Board approved a University Libraries Section preconference on library networks and also a preconference on "People in the World of Special Collections" to be held in Los Angeles sponsored by the Rare Books and Manuscripts Section.

As this ACRL president leaves office there are many persons to whom thanks are due-the other officers, many committee chairmen and members, numerous Association members, and the devoted office staff at Headquarters. A special note of thanks is reserved for two colleagues, however, Russell Shank, director of libraries, the Smithsonian Institution and J. Donald Thomas. Russ becomes ACRL president at the close of the Chicago Conference; I hope that I shall be, at the least, half as helpful to him as he has been to me this past year. Don left Headquarters and the post of ACRL Executive Secretary on May 31 to go east and direct the new undergraduate library at the University of Maryland. I am sure that all of ACRL's 11,000 members ioin me in best wishes to both.

JOSEPH H. REASON President, ACRL

몸

ACRL Membership

May 31, 1972

11,313

May 31, 1971

11,073

May 31, 1970

10,965 